department for the virtues of multiple and pluralistic approaches to the study of politics. In this respect, many of us recall what a generous mentor he was to his junior colleagues, regardless of the type of political science in which they engaged. He encouraged each of us to think independently, to formulate problems and methods we thought important, and to develop our own approaches with confidence. And he followed through in annual faculty review, promotion, and tenure meetings, in which he explained and defended our achievements to senior colleagues.

Giacomo's teaching contributions were also very significant for departmental development at both the graduate and undergraduate levels. He was a core figure in the graduate program, chairing the Graduate Studies Committee, and teaching the basic comparative methods and theory course and newly developed courses on comparative political parties and comparative voting behavior. To undergraduates, Giacomo brought a voice of experience and realism into courses on European politics.

Apart from his contributions while at Ohio State to both scholarship and teaching, Giacomo added another important ingredient to the life of the department. He was for a long time the only non-American faculty member among many who were raised and educated in the Midwest. His cosmopolitan manner and European perspective broadened our intellectual horizons and, indeed, our palates. Two of our now senior colleagues, Herb Weisberg and Herb Asher, fondly recall enjoying calamari for the first time in Giacomo's home on Erie Road in the quiet old-fashioned suburb of Clintonville just north of the Ohio State campus. Bill Liddle remembers hours of conversation accompanied by countless after-dinner cups of strong coffee made in Giacomo's classic stovetop espresso pot. For awhile, Bradley Richardson and Giacomo engaged in real estate speculation (not necessarily successfully) through the vehicle of San-Rich enterprises. Herb Asher fondly remembers heading out with Giacomo and Bradley on Saturday mornings to the Huddle for the breakfast special-two eggs over easy, hash browns, sausage, toast, coffee, and great conversation. All of these fond memories speak to how another former colleague, John Champlin, described Giacomo: "He had the gift of friendship and gave it with both hands."

In 1988, Giacomo began splitting his time between Ohio State and the Univer- sity of Pavia. He continued to teach at Ohio State for part of each academic year, but then resigned his position in the autumn of 1991 after making important contributions to our collective enterprise in research, teaching, and service for more than two decades. He became an emeritus professor at Ohio State in 1992. When Giacomo departed Columbus, he left behind many good friends, and he was sorely missed.

Richard Gunther
Ohio State University
R. William Liddle
Ohio State University
Goldie Shabad
Ohio State University

\section{JULIUS SMULKSTYS}

Julius Smulkstys was born in Kaunas, Lithuania, in 1930 and came to the United States with his parents as a refugee in 1949. He grew up in Chicago. He received his BA and MA degrees in political science from the University of Illinois, Champaign/ Urbana, and completed his Ph.D. at Indiana University-Bloomington in 1963.

Julius started teaching at what was then known as the Indiana University Center in 1959. He was the founder of the department of political science, first on the IU Fort Wayne campus and then at the Indiana University-Purdue University Fort Wayne campus. He served as chair until 1978.

Julius also served as Dean of the School of Arts and Letters from 1981 to 1988 and then as Acting Dean of the School of Arts and Sciences from 1988 to 1989 . He retired in 1995 at the rank of associate professor of political science/emeritus.

Julius was committed to faculty governance and spent much time setting up not only the department of political science, but also the emerging university in Fort Wayne that eventually combined the services offered by Indiana University and Purdue University in northeast Indiana.

Julius' main academic contribution was his book on Karl Marx, published in New York by Twayne Publishers (World Authors Series) in 1974. He also wrote on Lithuanian politics. His teaching focus was Marxist theory, totalitarian systems, and East European politics.

His love for his homeland never abated. Following the end of the Cold War, he became active in the democratization and liberalization of Lithuania. Following his retirement, Julius spent a lot of time in Lithuania. In 1998, he became advisor to Lithuanian President Valdas Adamkus. He was presidential liaison on Lithuanian-Jewish relations. He also served on the International Commission for the Evaluation of Crimes of the Nazi and the Russian Occupation Regimes in Lithuania. For his services, in February of 2010, he was awarded the highest civilian recognition offered by the Lithuanian government, that of the Cross of the Commander of the Order of the Lithuanian Grand Duke Gediminas.

Survivors include his wife, Isabel; daughter, Inga Smulkstys and her husband, Christopher Klose, of Washington, DC; a son, Linas Smulkstys, and his wife, Katie Smulkstys, of Chicago; grandchildren Noah and Lina Klose; and his brother, Liudas Smulkstys of Lemont, Illinois.

\section{Van Coufoudakis Indiana University Purdue University Fort Wayne}

\section{ROBERT C. TUCKER}

Robert C. Tucker died on July 29, 2010, at the age of 92 . He was an outstanding teacher and mentor at Indiana University from 1958 to 1961, and from 1962 to 1984 at Princeton University. He had a special gift for encouraging and assisting former graduate students, whom he viewed as colleagues and friends. His generosity and graciousness were much appreciated by the present writer and many others.

Bob Tucker was an exceptionally insightful and multifaceted Sovietologist. His viewpoints were shaped by nine years (1944-53) of diplomatic and translation work in wartime and postwar Russia (including persistent efforts to bring his Russian wife to the United States), by wideranging interdisciplinary interests in the social sciences and humanities (notably psychology, sociology, history, and philosophy), and by pioneering efforts to benefit from and contribute to comparative political studies (especially theories of leadership and culture).

Tucker's Harvard University doctoral dissertation was in philosophy and challenged the dominant interpretations of Soviet and Western theorists. He linked the ideas of the young and mature Marx and emphasized their "moralist," "ethical," and "religious" rather than political, economic, and social "essence." Hs revised dissertation was published as Philosophy and Myth 